\title{
ANALISIS KEMAMPUAN BERPIKIR KRITIS MATEMATIS MAHASISWA CALON GURU DITINJAU DARI COGNITIVE STYLE BERDASARKAN FIELD INDEPENDENT DAN FIELD DEPENDENT DI UNIVERSITAS ISLAM RIAU
}

\author{
Sari Herlina ${ }^{a}$, Agus Dahlia ${ }^{b}$ \\ a Program Studi Pendidikan Matematika FKIP UIR \\ J1. Kaharuddin Nasution No. 113 Perhentian Marpoyan, Pekanbaru \\ sariherlina99@edu.uir.ac.id \\ ${ }^{\mathrm{b}}$ Program Studi Pendidikan Matematika FKIP UIR \\ Jl. Kaharuddin Nasution No. 113 Perhentian Marpoyan, Pekanbaru \\ agus.dahlia@edu.uir.ac.id
}

\begin{abstract}
ABSTRAK
Penelitian ini adalah penelitian kualitatif yang bertujuan mengungkapkan secara mendalam analisis kemampuan berpikir kritis matematis mahasiswa berdasarkan gaya kognitif yaitu gaya kognitif field dependent dan gaya kognitif field independent. Sampel penelitiannya adalah mahasiswa matematika semester ganjil tahun ajaran 2017/2018. Instrumen penelitiannya adalah lembar tes GEFT dan tes kemampuan berpikir kritis matematis, sedangkan teknik pengumpulan datanya adalah teknik tes yang terdiri dari tes GEFT dan tes kemampuan berpikir kritis matematis dan teknik nontes yaitu angket terbuka, observasi partisipatif, dan dokumentasi. Analisis data yang dilakukan adalah data reduction, data display, dan conclusion drawing/verification. Kemudian Uji keabsahan data dalam penelitian kualitatif meliputi uji kredibilitas data, uji transferability, uji dependability, dan uji confirmability. Hasil penelitian ini menunjukkan bahwa hasil tes GEFT mahasiswa calon guru matematika semester 1 TA. 2017/2018 di Universitas Islam Riau menunjukkan bahwa dari dua Kelas A, terdapat 26 mahasiswa yang memiliki gaya kognitif Field Dependent (FD), dan 22 mahasiswa memiliki gaya kognitif Field Independent (FI). Untuk kelas B, terdapat 22 mahasiswa memiliki gaya kognitif Field Dependent (FD) dan 32 mahasiswa memiliki gaya kognitif Field Independent (FI), sedangkan berdasarkan analisis kemampuan berpikir kritis dan gaya kognitif mahasiswa, tidak terdapat perbedaan yang signifikan antara mahasiswa yang memiliki gaya kognitif Field Dependent dengan mahasiswa yang memiliki gaya kognitif Fied Independent.
\end{abstract}

Kata Kunci : Gaya Kognitif, Field Dependent, Field Dependent, Berpikir kritis matematis.

\section{ABSTRACT}

This research is qualitative research aim to explore with deep analisys mathematics critical thinking ability of students based on cognitive style that is field dependent and field independent. Sample for this research is mathematic students on odd semester in 2017/2018. This research instrument are sheet of GEFT test and critical thinking ability of mathematics test, whereas technique of data aggregate are technique test which is GEFT test and critical thinking ability of mathematics test and technique of non-test that are open quisioner, partisipatif observation, and documentation. Data's analysis with reduction of data, display of data, and conclusion drawing/verification. Afterwards, experiment of validity of data in this qualitative research envelop credibilities of data test, transferability test, dependability test and confirmability test. At the end, result of this research show that are result from students' GEFT test of candidate teacher in mathematics on odd semester 
in 2017/2018 in Universitas Islam Riau show that are both 2 class, in class A which have 26 student with Field Dependent of Cognitive Style, and 22 student with Field Independent of Cognitive Style, while in class B which have 22 student Field Dependent of Cognitive Style and 32 student have Field Independent of Cognitive Style. Then, based on critical thinking ability of mathematic and cognitive style, there was not significant different of ability between cognitive style of student's Field Dependent and student's Field Independent.

Keyword : Cognitive Style, Field Dependent, Field Dependent, Mathematics Critical Thinking Ability.

\section{Pendahuluan}

Dalam dunia pendidikan, keberhasilan dalam proses pembelajaran banyak faktor yang mempengaruhinya salah satunya adalah peran seorang pendidik dalam memahami kondisi perserta didiknya. Hal ini disebabkan karena setiap perserta didik mempunyai karakter yang berbeda satu dengan lainnya, karena itu setiap individu dapat dikatakan unik. Keunikan atau perbedaaan karakter dalam diri peserta didik sangatlah mempengaruhi gaya belajarnya, gaya belajar seseorang dapat dipengaruhi kecerdasaan, kemampuan berpikir dan kecakapannya dalam memecahkan masalah. Oleh karena itu, peserta didik mempunyai cara yang berbeda dalam belajar, menerima informasi, menyimpan informasi yang ada, mengorganisasikan setiap informasi, serta mengaplikasikan pengetahuan yang dimilikinya. Perbedaaan-perbedaan karakter setiap pererta didik dalam menyimpan, menyususun, dan mengolah/ mengorganisasikan informasi yang ada dapat dikatakan sebagai gaya kognitif.
Gaya kognitif merupakan karakteristik seseorang dalam menggunakan fungsi kognitifnya yaitu caramenerima informasi serta mengolah informasi tersebut berdasarkan pengalaman-pengalaman yang dimiliki. Sependapat dengan penelitian Within, dkk (dalam Blanton, 2004: 5) "indicated that cognitive style that cognitive styles exist and affect the way individuals assimilate and proses information and express what they know", sedangkan menurut Basey (dalam Nugraha dan Santy, 2016) mengungkapkan bahwa gaya kognitif merupakan proses atau gaya kontrol yang muncul dalam diri siswa yang dalam mengorganisasikan mengatur, menerima, dan menyebarkan informasi dan juga menentukan perilaku siswa tersebut.

Gaya kognitif dalam psikologi mempelajari tentang 2 hal yaitu gaya kognitif dari field independent dan field dependent (Blanton, 2004: 5).Menurut Daniels (dalam Altun dan Cakan, 2006: 291) bahwa siswa yang memiliki gaya kognitif field independent berkarakteristik: memahami obyek yang 
terpisah dari lingkungan, memisahkan dari bagian-bagian yang tidak relevan, menciptakan struktur meskipun struktur itu tidak inheren di dalam informasi yang ada, mereorganisasi informasi untuk memberi konteks bagi informasi sebelumnya, cenderung lebih efisien dalam mengingat bagian-bagian informasi lama. Wiktin, dkk (1979: 8-14), mengidentifikasi ciri-ciri gaya kognitif field dependent sebagai berikut: cenderung untuk berpikir global, cenderung untuk menerima struktur yang sudah ada, memiliki orientasi rasional, cenderung memiliki profesi yang menekankan keterampilan sosial, cenderung mengikuti tujuan yang sudah ada, cenderung bekerja dengan motivasi eksternal serta lebih tertarik pada penguatan eksternal.

Berdasarkan uraian di atas seorang pendidik atau dosen harus memiliki keterampilan dan kemampuan dalam memahami karakteristik dari peserta didiknya. Pengalaman peneliti mengajar kalkulus di prodi pendidikan matematika FKIP UIR, peneliti menemukan bahwa masing-masing mahasiswa memliki perbedaan cara dan gaya dalam menyelesaikan permasalahan matematika. Ada beberapa mahasiswa dalam menyelesaikan permasalahan masih mengikuti pola yang lama sebagaimana yang diajarkan di sekolahnya yang terdahulu. Beberapa mahasiswa yang lain senang berdiskusi dengan teman sebelahnya, ada juga yang mencoba memahami buku pegangan yang mereka miliki. Perbedaan gaya belajar yang mereka alami kemungkinan karena pada umumnya mahasiswa berasal dari sekolah yang berbeda. Melihat kondisi tersebut faktor lingkungan sangat mempengaruhi gaya kognitif mahasiswa.

Selain itu, diskusi dengan beberapa mahasiswa pendidikan matematika, mereka mengatakan bahwa faktor pendidik sangat mempengaruhi mereka dalam menerima informasi yang diberikan. Mahasiswa tersebut juga mengatakan, pendidik yang cendrung kepada mahasiswa yang pintar saja dalam proses pembelajaran sangat mempengaruhi minatnya dalam menerima serta menyerap informasi. Sebaliknya, apabila pendidik mampu memahami mereka akan sangat mempengaruhi minatnya untuk belajar. Namun demikian, untuk dapat meningkatkan mutu pendidikan, pendidik perlu mengetahui gaya kognitif mahasiswanya termasuk Field Independent atau Field Dependent.

Di dalam proses pembelajaran di kelas, mahasiswa yang memiliki karakteristik gaya kognitif field dependent akan cendrung fokus pada gambaran umum, 
hanya mengikuti informasi yang sudah diberikan, namun dapat bekerja sama dengan baik karena orientasi sosialnya. Pada mahasiswa dengan karakteristik gaya kognitifnya field independent akan cendrung mampu mencari informasi lebih banyak dari konten yang diberikan, mampu membedakan suatu objek disekitarnya dengan mudah, cendrung analitik dan motivasinya bergantung pada motivasi internal.

Hal ini menunjukkan pentingnya gaya kognitif menjadi perhatian pendidik/ dosen untuk memahami karakteristik setiap peserta didiknya. Berdasarkan hasil penelitian Tinarjero dan Purnomo (dalam Blanton, 2004: 6) mengungkapkan bahwa: "Research in the area of cognitive styles indicated that field independent subjects perform better (on standardized test) than field dependent subject, whether assessment is of specific discipline or across the even though FDI is entirely separate from intelligence".

Dengan demikinan, pendidik/dosen dapat merancang pembelajaran berdasarkan gaya kognitif mahasiswa. Kemampuan dan keterampilan pendidik/dosen dalam merancang pembelajaran berdasarkan gaya kognitifnya tentu akan berdampak positif terhadap hasil belajar peserta didiknya.Sejalan dengan pendapat Slavin (2006: 59) yang mengatakan "apabila seorang guru melakukan penilaian psikologis terhadap pertumbuhan kognitif siswanya, maka hal tersebut akan memberikan keuntungan terhadap siswa”. Sehingga seorang pendidik/dosen dalam merancang pembelajaran haruslah memandang perbedaan karakteristik setiap individu. Hal ini berarti penyampaian materi pembelajaran harus mempertimbangkan gaya kognitif peserta didiknya yaitu disesuaikan dengan karakteristik dan potensi yang dimiliki. Selain itu, pendidik/dosen dapat juga merancang bahan ajar yang disesuaikan dengan gaya kognitif mahasiswanya yang berdasarkan field independent dan field dependent.

Berdasarkan uraian di atas, sebelum merancang pembelajaran maupun bahan ajar yang disesuaikan dengan gaya kognitif mahasiswa, perlulah diketahui bagaimana gaya kognitif mahasiswa tersebut. Selaian itu, di dalam pembelajaran matematika untuk tingkat pendidikan perguruan tinggi diharapkan mahasiswa mempunyai kemampuan berpikir kritis. Kemampuan berpikir kritis matematis merupakan salah satu kemampuan berpikir tingkat tinggi (high order thingking).Supaya mahasiswa mampu memiliki kemampuan tersebut, maka mahasiswa tersebut harus memiliki pemahaman konsep yang baik dan komperensif. Oleh karena itu, peneliti tertarik untuk melakuan penelitian awal 
yaitu mengkaji tentang "Analisis

Kemampuan Berpikir Kritis Matematis

Mahasiswa Calon Guru ditinjau dari Cognitive Style berdasarkan field independent dan field dependent di Universitas Islam Riau”.

\section{Metode Penelitian}

Jenis penelitian yang digunakan dalam penelitian ini adalah penelitian kualitatif. Pemilihan penelitian kualitatif tersebut didasari oleh tujuan peneliti yang ingin mengungkapkan secara mendalam analisis kemampuan berpikir kritis matematis mahasiswa berdasarkan gaya kognitif siswa menurut Witkin, dkk (1979: 8-14), yaitu gaya kognitif field dependent dan gaya kognitif field independent.

Penelitian dilaksanakan di Program Studi Pendidikan Matematika FKIP Universitas Islam Riau, yang beralamatkan di Jalan Kaharudin Nasution No. 113 Perhentian Marpoyan, Pekanbaru. Penelitian ini akan dilaksanakan pada Semester Ganjil TA. 2017/2018, pada mata kuliah Kalkulus I.

Populasi dalam penelitian ini adalah seluruh mahasiswa matematika pada semester satu tahun ajaran 2017/2018. Sampel penelitiannya adalah Mahasiswa Semester I di Pendidikan Matematika FKIP Universitas Islam Riau Tahun Ajaran 2017/2018. Pemilihan sampel penelitian berdasarkan teknik pengambilan sampling jenuh. Hal ini dikarenakan seluruh populasi dalam penelitian ini digunakan sebagai sampel penelitian. Sehingga dalam penelitian ini sampel penelitian adalah mahasiswa semester satu kelas 1A dan 1B pada matakuliah kalkulus 1.

Instrumen penelitiannya adalah lembar tes GEFT dan tes kemampuan berpikir kritis matematis, sedangkan teknik pengumpulan datanya adalah teknik tes yang terdiri dari tes GEFT dan tes kemampuan berpikir kritis matematis dan teknik nontes yaitu angket terbuka, observasi partisipatif, dan dokumentasi. Kriteria pengelompokkan gaya kognitif mahasiswa berdasarkan Field Dependent dan Field Independent ditunjukkan pada tabel berikut:

Tabel 1. Kategori Skor GEFT

\begin{tabular}{clc}
\hline No & Gaya Kognitif & Skor GEFT \\
\hline $\mathbf{1}$ & Field Dependent & $0-9$ \\
$\mathbf{2}$ & Field Intermediate & $10-13$ \\
$\mathbf{3}$ & Field Independent & $14-18$ \\
\hline \multicolumn{3}{c}{ Sumber : Idris (dalam Ulya, 2015) }
\end{tabular}

Selanjutnya mahasiswa yang memiliki skor nilai tengah dari kelompok FD lemah disebut FD Lemah (FDL), sedangkan mahasiswa yang memiliki skor nilai tengah dari kelompok FD kuat disebut FD Kuat (FDK). Kondisi yang sama juga diterapkan pada mahasiswa dengan gaya kognitif FI. Mahasiswa yang memiliki skor nilai tengah dari kelompok FI lemah 
disebut FI Lemah (FIL) dan mahasiswa yang memiliki skor nilai tengah dari kelompok FI kuat disebut FI Kuat (FIK).

Analisis data yang dilakukan adalah data reduction, data display, dan conclusion drawing/verification. Kemudian Uji keabsahan data dalam penelitian kualitatif meliputi uji kredibilitas data, uji transferability, uji dependability, dan uji confirmability.

\section{Hasil dan Pembahasan}

\section{Analisis Hasil Tes GEFT}

Tes GEFT adalah tes untuk melihat gaya kognitif mahasiswa. Hasil tes GEFT akan dibagi ke dalam 3 kategori Gaya Kognitif yakni Field Dependent, Field Intermediete, dan Field Independent.Tes ini diberikan kepada 96 orang mahasiswa pendidikan matematika pada semester satu tahun ajaran 2017/2018. Hasil tes GEFT dapat dilihat dalam tabel berikut:

Tabel 2. Hasil Tes GEFT pada

Mahasiswa Matematika

\begin{tabular}{llccc}
\hline No. & \multicolumn{1}{c}{ Gaya } & \multicolumn{2}{c}{ Kelas } & Total \\
\cline { 2 - 3 } & $\begin{array}{l}\text { Kognitif } \\
\text { 1. }\end{array}$ & F & F & \\
& $\begin{array}{l}\text { Feld } \\
\text { Dependent }\end{array}$ & 19 & 22 & 41 \\
2. & $\begin{array}{l}\text { Field } \\
\text { Intermediete }\end{array}$ & 15 & 19 & 34 \\
3. & $\begin{array}{l}\text { Field } \\
\text { Independent } \\
\text { Total }\end{array}$ & 14 & 7 & 21 \\
& 48 & 48 & 96 \\
\hline
\end{tabular}

Pada tabel di atas terlihat bahwa mahasiswa yang gaya kognitif dalam kelompok Field Dependent lebih banyak dari mahasiswa yang gaya kognitifnya Field Independent. Dari kedua ke kelas yang diberikan tes GEFT ini yaitu mahasiswa kelas A dan kelas B, kecendrungan gaya belajar kognitifnya cenderung Field Dependent daripada Field Independent. Ini berarti mahasiswa cendrung menerima pendapat atau pertimbangan dari teman atau guru dan mengutamakan motivasi eksternal, perlu bimbingan cara memecahkan masalah, berorientasi sosial atau lingkungan.

Pada kelompok Field Intermediete artinya mahasiswa ini ada dalam kategori Field Dependent lemah dan Field Independent lemah. Rentang skor pada kelompok Field Intermediete10-13, apabila mahasiswa yang memperoleh skor kurang dari sama dengan 12 maka termasuk kategori Field Dependent lemah dan apabila mahasiswa memperoleh skor lebih dari sama dengan 12 maka termasuk kategori Field Independent lemah. Di lihat dari tabel di atas pada kelas A mahasiswa yang termasuk kelompok Field Intermedietehampir sama dengan kelompok mahasiswa Field Independent, sedangkan pada kelas B jumlah mahasiswa kelompok Field Intermediete lebih banyak daripada mahasiswa kelompok Field Independent. Hal ini menunjukkan gaya kognitif kedua kelas ini berbeda, satu kelas lebih cendrung interpersonal (perorangan) dan kelompok 
satu lagi cendrung berorientasi pada lingkungan atau sosial.

Apabila data tentang gaya kognitif di atas hanya dibagi ke dalam dua kelompok yaitu: Field Dependent dan Field Independent, maka perbandingannya dapat dilihat dalam diagram batang berikut:

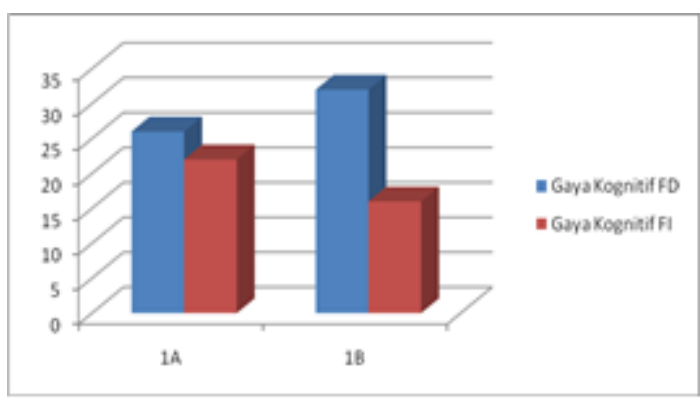

Gambar 1. Perbandingan Gaya Kognitif

Field Dependent dan Field Independent

Pada gambar di atas, kelompok Field Intermediete dimasukkan dalam kelompok Field Independent lemah dan Field Dedependent lemah. Terlihat berbeda dari kelas di atas, pada kelas 1A mahasiswa yang gaya kognitif Field Dependent hampir sama dengan gaya kognitif Field dependent, sedangkan pada kelas 1B gaya kognitif perbandingan gaya kognitif Field Dependent dan gaya kognitif Field Independent hampir 2:1.
Hal ini menunjukkan setiap kelas mempunyai gaya belajar yang berbedabeda.

2. Analisis Hasil Tes Kemampuan Berpikir Kritis

Analisis hasil tes kemampuan berpikir kritis bertujuan untuk melihat bagaimana kondisi kemampuan berpikir kritis mahasiswa ditinjau dari gaya kognitif. Pada penelitian ini, indikator berpikir kritis yang diambil ada enam berdasarkan teori Ennis (2011) yaitu: 1) Mengatakan kebenaran pertanyaan/pernyataan; 2) Menganalisis pertanyaan/pernyataan; 3) Mengurutkan, misalnya secara temporal, secara logis, secara sebab akibat; 4) Mengklasifikasi, misalnya gagasan-gagasan, objek-objek; 5) Memutuskan, misalkan apakah cukup bukti; 6) Memprediksi (termasuk membenarkan prediksi). Indikator 1 dan 2 untuk soal nomor 2, indikator 3 dan 4 untuk soal nomor 1 dan indikator 5 dan 6 untuk soal nomor 3. Hasil tes kemampuan kritis matematis dirangkum dalam tabel berikut: 
Tabel 3 . Hasil Tes Kemampuan Berpikir Kritis Matematis

\begin{tabular}{llllllll}
\hline Kelas & $\begin{array}{c}\text { Jumlah } \\
\text { Siswa }\end{array}$ & \multicolumn{6}{c}{ Jumlah siswa yang memperoleh skor 0-3 dan 4- } \\
& & & \multicolumn{5}{c}{ 5 pada setiap soal } \\
\cline { 3 - 8 } & & $0-3$ & $4-5$ & $0-3$ & $4-5$ & $0-3$ & $4-5$ \\
& 49 & - & - & - & - & - & - \\
1A & 49 & 46 & 3 & 49 & 0 & 47 & 2 \\
1B & 49 & $93,88 \%$ & $6,12 \%$ & $100,00 \%$ & $0,00 \%$ & $95,92 \%$ & $4,08 \%$ \\
\hline
\end{tabular}

Pada tabel di atas, tes dilakukan hanya pada kelas 1B. Hal ini dikarenakan pada kelas 1A materi yang diujikan belum selesai disampaikan dosen yang mengajar di kelas tersebut. Dilihat secara keseluruhan skor mahasiswa di atas menunjukkan bahwa rata-rata skor yang memperoleh skor 0-3 sebesar 96,6\% dari tiga soal, sedangkan rata-rata skor yang memperoleh skor 4-5 sebesar 3,4\%. Hal ini menunjukkan kemampuan berpikir kritis mahasiswa masih rendah atau belum berkembang.

Jika ditinjau dari gaya belajar kognitif, pada soal nomor 1 mahasiswa yang memperoleh skor 4-5 ternyata gaya belajar kognitifnya satu kelompok Field Independent dan yang dua lagi dari kelompok Field Dependent. Pada soal nomor tiga, yang mampu memperoleh skor 4-5 dari satu orang kelompok Field Independent dan dua orang dari kelompok Field Intermediate. Apabila kita memperhatikan data ini, maka gaya belajar setiap individu itu berbeda-beda namun tetap dapat membuat mahasiswa mampu untuk memperoleh hasil yang sama.

3. Analisis Angket Terbuka

Berdasarkan hasil pengisian angket terbuka, dalam penelitian ini dibagi berdasarkan gaya belajar kognitifnya yakni Field Dependent, Field intermediate, dan Field Independent. Pertanyaan dalam angket tersebut diarahkan kepada ciri-ciri dari cognitive style/gaya kognitif berdasarkan kajian teorinya.

Dalam kelompok Field Dependent, saat ditanya tentang faktor-faktor apa yang mempengaruhi mereka untuk belajar, jawaban yang mereka sampaikan secara umum hampir sama yakni: 1) faktor kelas yang nyaman, 2) faktor dosen, 3) faktor teman, teman yang memberikan semangat belajar, 4) posisi duduk. Dari keempat faktor tersebut terlihat bahwa mahasiswa yang gaya kognitifnya Field Dependent faktor lingkungan sangat mempengaruhi mereka untuk belajar.

Telihat bahwa mahasiswa dengan haya kognitif Field Independent lebih 
mempunyai kemauan untuk belajar sendiri, dan faktor guru bukan yang utama. Dalam kondisi ini, mahasiswa cendrung mempunyai kemampuan personal lebih baik dari Field Dependent.

Pembahasan

Dari hasil penelitian diperoleh bahwa kemampuan berpikir kritis mahasiswa dengan gaya kognitif FD tidak jauh berbeda dengan kemampuan berpikir kritis mahasiswa dengan gaya kognitif FI. Hal ini dapat dilihat dari hasil analisis tes kemampuan berpikir kritis, terdapat 2 mahasiswa dengan gaya kognitif FD mampu mendapatkan skor antara $4-5$ pada soal nomor 1. Pada soal ini mahasiswa tersebut dianggap mampu mengurutkan secara logis dan sebab akibat suatu masalah, selain itu mahasiswa dianggap mampu mengklasifikasi gagasan-gagasan atau objek-objek. Akan tetapi, mahasiswa dengan kelompok FD masih banyak yang termasuk dalam kelompok yang mendapatkan skor, yang jumlahnya mencapai 93,75\%. Mahasiswa dengan gaya kognitif FD ini tidak dapat mengklasifikasi gagasan-gagasan atau objek-objek yang diberikan pada masalah dan tidak dapat menjelaskan sebab akibat dari masalah tersebut. Mahasiswa dengan kemampuan FD hanya mampu menuliskan hal yang ditanyakan, tetapi tidak dapat mengurutkan dan mengklasifikasi masalah tersebut.

Pada soal kedua, tidak terdapat satu orangpun mahasiswa FD yang termasuk dalam kelompok skor 4-5, yangdianggap mampu meneyelesaikan permasalahan yang diberikan. Hal ini menunjukkan bahwa mahasiswa FD tidak dapat menganalisis masalah yang diberikan sehingga mahasiswa tidak mampu untuk mengatakan kebenaran pernyataan.

Untuk soal ketiga, mahasiswa FD juga tidak ada yang termasuk kedalam kelompok dengan skor $4-5$. Hal ini menunjukkan bahwa, mahasiswa FD dianggap kurang dapat memprediksi dan memutuskan bukti - bukti yang ada di permasalahan yang diberikan.

Berdasarkan hasil tes kemampuan berpikir kritis, mahasiswa calon guru matematika FKIP semester 1 TA. 2017/2018 yang termasuk kedalam kategori FD dianggap belum dapat memberikan penjelasan sederhana, penjelasan lanjut, teknik, dan menyimpulkan dengan baik dari suatu masalah. Sehingga dapat disimpulkan mahasiswa calon guru matematika FKIP semester 1 TA. 2017/2018 dengan gaya kognitif FD masih sangat lemah dalam berpikir kritis.

Berdasarkan Skor GEFT, Menurut Idris (dalam Ulya, 2015), subjek dengan skor tes GEFT berada diantara $14-18$ 
termasuk kedalam kategori Field Independent (FI). Dimana subjek yang termasuk kedalam kategori ini dianggap mampu menganalisis dan lebih sistematis dalam menerima informasi lebih baik dibandingkan subjek yang termasuk dalam kategori FD.

Pada soal yang mengukur kemampuan mengklasifikasi dan mengurutkan masalah, yaitu soal nomor 1 , hanya 1 mahasiswa yang termasuk ke dalam kategori skor $4-5$, yakni hanya sebesar 6,25\%. Sedangkan dari kelompok FD, terdapat 2 mahasiswa yang termasuk ke dalam kategori skor 4 - 5 dimana juga hanya sebesar 6,25\%. Selain itu, berdasarkan hasil analisa jawaban kedua kelompok ini yang termasuk kedalam skor 4 - 5 memiliki kemampuan yang sama dalam mengklasifikasi dan mengurutkan masalah.

Pada indikator soal menyatakan kebenaran dan menganalisis pernyataan, yaitu soal nomor 2, tidak ada satu mahasiswa dari kelompok FI yang termasuk kedalam kategori skor $4-5$. Hal ini juga terjadi pada mahasiswa kelompok FD, dimana mahasiswa kelompok FD juga tidak ada yang termasuk kedalam kategori skor $4-5$. Hal ini menunjukkan bahwa untuk kemampuan menganalisis dan menyatakan kebenaran pernyataan, mahasiswa kelompok FI dan FD memiliki kemampuan yang sama, yakni mahasiswa masih kurang dalam indikator ini.

Untuk indikator terakhir, yaitu memprediksi dan memutuskan, hanya terdapat 1 mahasiswa kelompok FI yang mendapatkan skor 5, dan menjadi satusatunya mahasiswa yang termasuk ke dalam kategori skor 4 - 5. Berdasarkan dari analisis jawaban, mahasiswa tersebut mampu menyelesaikan dengan baik masalah yang diberikan.

Berdasarkan hasil tes berpikir kritis, dapat disimpulkan bahwa mahasiswa calon guru matematika semester 1 TA. 2017/2018 di Universitas Islam Riau yang termasuk kedalam kategori FI, masih lemah dalam berpikir kritis. Hal ini disebabkan masih terdapat sebesar 93,75\% mahasiswa FI yang termasuk kedalam kategori skor 0 3. Hal ini menunjukkan bahwa mahasiswa dengan gaya kognitif yang sama tidak selalu memiliki kemampuan berpikir kritis yang sama.

Dilihat dari perbedaan hasil tes berpikir kritis, untuk mahasiswa calon guru semester 1 TA. 2017/2018 di Universitas Islam Riau, dapat disimpulkan bahwa belum tentu mahasiswa yang termasuk kedalam kategori FI lebih baik kemampuan berpikir kritisnya dibandingkan dengan mahasiswa yang termasuk kedalam kategori FD. Hal ini dilihat dari pengelompokkan skor, untuk skor $0-3$ terdapat mahasiswa dengan 
kategori FI dan mahasiswa kategori FD dengan persentase yang sama, yaitu 93,75\%. Sedangkan untuk kategori skor 4 - 5, kedua kelompok mahasiswa ini memiliki jumlah persentase yang sama yaitu sebesar 6,25\% untuk masing-masing kelompok.

Akan tetapi, bedasarkan indikatorindikator berpikir kritis, mahasiswa kelompok FI memiliki kemampuan berpikir kritis dalam jumlah indikator lebih banyak dibandingkan kelompok FD. Dari hasil tes terlihat mahasiswa dengan kelompok FI mampu menyatakan kebenaran pernyataan, menganalisis pernyataan, memprediksi, dan memutuskan suatu masalah telah memiliki cukup bukti. Sedangkan mahasiswa kelompok FD, hanya mampu menyelesaikan soal dengan indikator mengklasifikasi dan mengurutkan objekobjek yang terdapat dalam masalah yang diberikan.

Dari angket terbuka yang disebarkan kepada mahasiswa, diperoleh hasil bahwa terdapat perbedaan antara mahasiswa dengan gaya kognitif FI dan FD. Hal ini sesuai dengan yang diungkapkan oleh Witkin, dkk (1979: 8-14), dimana subjek yang termasuk dalam kategori FD, cenderung berorientasi pada sosial, sedangkan yang termasuk kategori FI, cenderung berorientasi impersional.
Dalam belajar, mahasiswa yang termasuk kedalam kategori FI, memiliki motivasi dari diri sendiri untuk belajar dan tidak bergantung kepada orang lain untuk memotivasi dirinya. Akan tetapi berdasarkan angket terbuka, mahasiswa dengan gaya kognitif FI merasa bantuan dari luar juga memotivasi minat belajarnya selain dari dalam dirinya sendiri. Selain itu, mereka juga menyukai cara belajar berkelompok dalam menyelesaikan masalah, walaupun mereka dapat menyelesaikan sendiri. Berbeda dengan kelompok FD, berdasarkan angket terbuka terlihat jelas bahwa mereka lebih menyukai belajar kelompok dari pada belajar sendiri, dan bantuan lingkungan sangat diperlukan dalam menyelesaikan masalah. Mahasiswa yang termasuk kelompok FD, tidak dapat memotivasi dirinya sendiri tanpa bantuan dari lingkungan sosialnya.Dalam angket terlihat bahwa mahasiswa kelompok FI dan FD memiliki kecenderungan cara belajar yang hampir sama, yaitu mereka lebih suka melalui pendekatan visual, dimana dosen menerangkan langsung didepan kelas daripada harus membaca sendiri buku referensi yang mereka punya.

Berdasarkan hasil penelitian, dapat dilihat bahwa cara belajar mahasiswa calon guru matematika semester 1 TA 2017/2018 di 
Universitas Islam Riau tidak terlalu berbeda. Sehingga, dapat disimpulkan bahwa sangatlah wajar hasil tes berpikir kritis mahasiswa kelompok FI dan FD tidak terlalu berbeda.

\section{Kesimpulan}

Berdasarkan hasil penelitian, diperoleh kesimpulan sebagai berikut :

1. Hasil tes GEFT mahasiswa calon guru matematika semester 1 TA. 2017/2018 di Universitas slam Riau menunjukkan bahwa dari dua Kelas A, terdapat 26 mahasiswa yang memiliki gaya kognitif Field Dependent (FD), dan 22 mahasiswa memiliki gaya kognitif Field Independent (FI). Untuk kelas B, terdapat 22 mahasiswa memiliki gaya kognitif Field Dependent (FD) dan 32 mahasiswa memiliki gaya kognitif Field Independent (FI).

2. Berdasarkan analisis kemampuan berpikir kritis dan gaya kognitif mahasiswa, tidak terdapat perbedaan yang signifikan antara mahasiswa yang memiliki gaya kognitif Field Dependent dengan mahasiswa yang memiliki gaya kognitif Fied Independent.

\section{Ucapan Terimakasih}

Terimakasih kami ucapkan kepada Lembaga Penelitian dan Pengabdian Masyarakat (LPPM) Universitas Islam Riau yang telah mendanai penelitian ini.

\section{Pustaka}

Altun, A., and Cakan, M.Undergraduate Student's Academic

Achievement, Field

Dependent/Independent

Cognitive Style and Attitude Toward Computers, 2006, www.ifets.info/journals/91/23.p df.

Blanton, E.L. 2004. The Influence Of Students' Cognitive Style On A Standardized Reading Test Administered In Three Different Formats. Online. Tersedia: http://etd.fcla.edu/CF/CFE00000 55/Blanton_Elizabeth_L_20040 5_EdD.pdf. Florida: The University of Central Florida.

Ennis, R. H. 2011. The Nature of Critical Thinking: Sn Outline of CriticalThinking Dispositions and Abilities. Online. Tersedia di http://faculty.education.illinois.e $\mathrm{du} /$ rhennis/documents/TheNatur eofCriticalThinking_51711_000. pdf. Diakses 9-03-2015. 
Nugraha, M.G dan Awaliyyah, S. 2016.

Analisis Gaya Kognitif Field

Dependent dan Field

Independent terhadap

penguasaan konsep Fisika Siswa

Kelas VII. Tersedia: Http:// snf-

unj.ac.id/index.php/download_file/view/8

27/191/. Diakses: 21 Maret

2017].

Slavin, R.E. 2006. Educational Physcology, Theory and

Practice, Eight Edition. Amerika:

Johns Hopkins University.

Ulya, H. 2014. Analisis Kemampuan

Pemecahan Masalah Matematika

SMP Ditinjau dari Gaya Kognitif

Siswa. Tesis. Universitas Negeri

Semarang.

Witkin et.al. 1979. Field Dependent and

Field Independent Cognitive

Styles and Their Educational

Implication, New York:

American Educational Research

Journal.

Witkin, dkk. 1971. A Manual For The

Embedded Figure Test.

California: Consulting

Psychologist Press 
